\title{
Energy Status, Lipid-Soluble Vitamins, and Acute Phase Proteins in Periparturient Holstein and Jersey Dairy Cows With or Without Subclinical Mastitis
}

\author{
P. Rezamand, ${ }^{* 1}$ T. A. Hoagland, ${ }^{*}$ K. M. Moyes, $†$ L. K. Silbart, ${ }^{\star 2}$ and S. M. Andrew ${ }^{\star 3}$ \\ *Department of Animal Science, University of Connecticut, Storrs 06269 \\ †Department of Animal Sciences, University of Illinois, Urbana 61801
}

\section{ABSTRACT}

In a retrospective, case-controlled, observational study, associations among indices of negative energy balance, plasma lipid and lipid-soluble vitamin concentrations, plasma acute phase protein status, and occurrence of a new subclinical intramammary infection (IMI) during the periparturient period were determined. Cows were paired based on breed and expected parturition date (EPD) and monitored from the cessation of lactation through wk 8 of the subsequent lactation. A cow was identified as developing a new IMI if the intramammary pathogen isolated postpartum differed from that isolated in wk -9 (relative to EPD). Mean body condition score (BCS) of cows at wk -9 was 3.71 \pm 0.12 . Fifteen Holstein and 15 Jersey dairy cows met the study selection criteria. Cows with a new IMI had greater body condition score, body weight, and body weight loss compared with cows that did not develop a new IMI. Prepartum plasma concentrations of $\beta$-carotene were greater for Jersey cows with a new IMI compared with Jersey cows without a new IMI and Holstein cows, regardless of IMI status. However, there was a significant delay in recovery of plasma concentrations of $\beta$-carotene postpartum for Jersey cows with a new IMI compared with Jersey cows without a new IMI. Plasma $\alpha$-tocopherol, albumin, and retinol binding protein concentrations were greater during the periparturient period for cows without a new IMI. Plasma haptoglobin was increased at wk 1 postpartum for cows without a new IMI. Milk protein and lactose percentages and milk urea $\mathrm{N}$ were decreased and somatic cell counts were increased in cows identified with a new IMI compared with cows that did not develop a new IMI. Dairy

Received January 17, 2007.

Accepted August 1, 2007.

${ }^{1}$ Present address: Department of Large Animal Clinical Sciences, Michigan State University, East Lansing, MI 48824.

${ }^{2}$ Present address: Department of Allied Health Sciences, University of Connecticut, Storrs 06269.

${ }^{3}$ Corresponding author: sheila.andrew@uconn.edu cows with greater tissue energy stores prepartum and reduced plasma proteins, $\beta$-carotene, and $\alpha$-tocopherol had a greater risk for developing a new IMI during the periparturient period.

Key words: energy status, lipid-soluble vitamin, subclinical mastitis

\section{INTRODUCTION}

The risk for developing metabolic disorders and diseases such as mastitis increases for dairy cows during the transition period and may be related to an impairment of immune function (Goff and Horst, 1997). Increases in DMI following parturition can lag behind increases in nutrient requirements for milk synthesis, resulting in a period of negative energy balance (NEB) that has been associated with a decrease in neutrophil and lymphocyte functions (Suriyasathaporn et al., 2000). Severe NEB resulting in ketosis was associated with an increase in oxidative stress and mastitis (Bernabucci et al., 2005). It is estimated that approximately $50 \%$ of all lactating cows develop some degree of subclinical ketosis; therefore, the increased risk for mastitis during the periparturient period may be associated with the degree of NEB and ketosis (Duffield, 2000).

Lipid-soluble vitamins also affect mammary gland health and immune function. Lymphocyte function, phagocytosis, and in vitro intracellular killing by blood neutrophils against Staphylococcus aureus were enhanced with increasing dietary $\alpha$-tocopherol, retinol, and $\beta$-carotene in dairy cows (Tjoelker et al., 1990; Erskine et al., 1997). In some studies, however, no associations were reported (Oldham et al., 1991; LeBlanc et al., 2004). The variability in results may have been due to differences in the vitamin concentrations in the basal ration, level of milk production, or the energy status of cows across the studies.

In an epidemiological study, LeBlanc et al. (2004) detected a significant inverse association between serum concentrations of retinol and mastitis during early lactation (first 30 DIM). Retinol is primarily transported by retinol binding protein (RBP) from the liver 
to target organs and is bound to transthyretin (TTR), which is a thyroid hormone transporter (Lindberg et al., 1999). Periparturient cows fed a diet with greater protein content had greater plasma RBP and retinol concentrations compared with cows fed a diet with lower protein content (Lindberg et al., 1999). Furthermore, plasma RBP and TTR were reduced in association with metabolic disorders such as hyperketonemia (Grohn and Lindberg, 1985). No information is currently available on the status of plasma RBP and TTR concentrations during the periparturient period in dairy cows, and whether occurrence of a new IMI is associated with reduction of plasma RBP or TTR in dairy cows. Also, changes in plasma RBP concentrations and other proteins such as haptoglobin (Hpt) have been used as indicators of an immune response and are part of the acute phase protein (APP) response (Humblet et al., 2006).

The objective of this study was to determine if there were associations among indices of NEB, lipid-soluble vitamin concentrations, and occurrence of subclinical new IMI during the periparturient period.

\section{MATERIALS AND METHODS}

\section{Animal Selection and Definition of New IMI}

Holstein and Jersey dairy cows with a BCS range of 2.50 to 4.00 at the end of lactation (first or greater) were eligible to be selected for the study. Final selection of cows for inclusion in the study was determined by new subclinical IMI status as described below. All cows selected were free from clinical signs of mastitis throughout the study period. Holstein and Jersey cows with median parity of 2 (ranging from 1 to 4 ) were paired based on breed and expected parturition date (EPD) and monitored from the cessation of lactation through 8 wk of the subsequent lactation. The mean BCS of selected cows was $3.71 \pm 0.12$ at dry off. Duplicate composite milk samples were collected aseptically at the cessation of lactation ( $-9 \mathrm{wk}$ relative to EPD) and at wk 1, 4, and 8 postpartum and analyzed for mastitis pathogens at the University of Connecticut Mastitis Laboratory (Storrs) as previously described (Andrew, 2000). Somatic cell counts were estimated from the aseptically collected milk samples using the California Mastitis Test (CMT) and were used in the identification of a new IMI. The following pathogens were identified: Staphylococcus aureus, Staphylococcus spp. (other than Staph. aureus), Streptococcus agalactiae, Streptococcus spp. (other than Strep. agalactiae), Escherichia coli, and Klebsiella spp. Each pair of cows was classified by new IMI status for the study period. The guidelines described by Hogan et al. (1990) were followed for identifying a cow as either acquiring a new
IMI or not acquiring a new IMI. A cow was identified as acquiring a new IMI (yes new IMI) if the pathogen isolated at each wk of bacteriological analysis postpartum differed from wk -9 (relative to EPD) culture results. If no intramammary (IMM) pathogens were isolated at any time point, the cow was identified as no new IMI. There were 9 cows with pathogens at wk -9 (dry off); 1 cow had 3 IMM pathogens and the sample was considered contaminated. Of the 9 cows identified with an IMI at dry off, 6 cows developed a new IMI postpartum (different organism and a CMT reaction of trace or greater.) Two cows had a minor IMM pathogen at dry off (Staphylococcus spp.) and no IMM pathogens were isolated postpartum with no reaction (0) on the CMT and were considered as not developing a new IMI. Staphylococcus aureus was cultured in milk from $1 \mathrm{cow}$ at dry off. Milk samples collected from this cow postpartum were negative for IMM pathogens and CMT reaction was 0 ; therefore, this cow was identified as no new IMI. The use of animals and all procedures of the study were approved by the Institutional Animal Care and Use Committee at the University of Connecticut.

\section{Management and Feeding}

Each cow was treated with an IMM antibiotic approved for nonlactating dairy cows at the cessation of lactation before the study. During the early dry period, cows were housed in a free-stall barn for approximately $6 \mathrm{wk}$ from late fall to spring or were rotationally grazed on mixed grass-legume pastures, when available. During the first 6 wk of the dry period for cows that were not grazed, a TMR (80\% forage, on a DM basis) was fed twice daily at approximately 0900 and $1600 \mathrm{~h}$ (data not shown). Two weeks before the EPD, all cows were fed a close-up prepartum TMR ad libitum. Feed ingredients and nutrient composition of the dry-period ration (close up) are shown in Table 1 . Approximately $1 \mathrm{~d}$ before calving, cows were moved to maternity pens. At parturition, intravenous dextrose and macrominerals $(\mathrm{P}, \mathrm{Ca}$, and $\mathrm{Mg}$ ) were administered to all cows during the first half of the study as per standard management protocol. During the second half of the study, at parturition, all cows were treated orally with macrominerals due to a change in management personnel. Following parturition, cows were moved to tie-stalls and monitored for $3 \mathrm{~d}$. If the general health status postparturition was considered normal, cows were moved to a single-row free-stall facility with access to feed and water at all times. Cows with clinical signs of mastitis, ketosis, or any other major health disorder were excluded from the final study selection. This allowed the investigation of potential associations among energy indices, lipidsoluble vitamins, and occurrence of only the subclinical 
Table 1. Feed ingredients and chemical composition of the prepartum and postpartum rations fed to 15 Holstein and 15 Jersey cows during the study period

\begin{tabular}{|c|c|c|}
\hline \multirow[b]{2}{*}{ Item } & \multicolumn{2}{|c|}{ Ration } \\
\hline & Prepartum & Postpartum \\
\hline \multicolumn{3}{|l|}{ Ingredient (\% of DM) } \\
\hline Alfalfa hay & 0.00 & 3.96 \\
\hline Mixed grass hay & 23.7 & 0.00 \\
\hline Grass silage $^{1}$ & 26.5 & 4.06 \\
\hline Corn silage $^{2}$ & 27.9 & 41.4 \\
\hline Beet pulp & 0.00 & 7.75 \\
\hline Megalac ${ }^{3}$ & 0.00 & 1.09 \\
\hline Protein supplement ${ }^{4}$ & 3.40 & 12.1 \\
\hline Energy supplement ${ }^{5}$ & 0.00 & 29.4 \\
\hline Pre-fresh grain mix $^{6}$ & 18.5 & 0.00 \\
\hline Sodium bicarbonate & - & 0.23 \\
\hline \multicolumn{3}{|l|}{ Nutrient content } \\
\hline $\mathrm{CP}$ & 14.4 & 16.6 \\
\hline Soluble protein & 5.76 & 6.10 \\
\hline $\mathrm{RDP}$ & 8.76 & 10.2 \\
\hline $\mathrm{ADF}$ & 27.8 & 20.7 \\
\hline $\mathrm{NDF}$ & 43.9 & 36.3 \\
\hline NFC & 31.4 & 36.7 \\
\hline $\mathrm{NE}_{\mathrm{L}}, \mathrm{Mcal} / \mathrm{kg}$ & 1.43 & 1.71 \\
\hline Ether extract & 3.54 & 4.17 \\
\hline $\mathrm{Ca}$ & 0.66 & 0.82 \\
\hline $\mathrm{P}$ & 0.37 & 0.41 \\
\hline $\mathrm{Mg}$ & 0.29 & 0.26 \\
\hline $\mathrm{K}$ & 1.74 & 1.23 \\
\hline
\end{tabular}

${ }^{1}$ Grass silage contained $35.2 \% \mathrm{DM}, 15.4 \% \mathrm{CP}$ (soluble protein: $53.3 \%$ of CP), $0.59 \% \mathrm{Ca}, 0.38 \% \mathrm{P}, 0.26 \% \mathrm{Mg}, 2.99 \% \mathrm{~K}$, and $1.23 \mathrm{Mcal} /$ $\mathrm{kg}$ of $\mathrm{NE}_{\mathrm{L}} / \mathrm{kg}$ of $\mathrm{DM}$.

${ }^{2}$ Corn silage contained $35.1 \% \mathrm{DM}, 8.08 \% \mathrm{CP}$ (soluble protein: $56.5 \%$ of $\mathrm{CP}$ ), $0.22 \% \mathrm{Ca}, 0.26 \% \mathrm{P}, 0.16 \% \mathrm{Mg}, 1.23 \% \mathrm{~K}$, and 1.60 Mcal of $\mathrm{NE}_{\mathrm{L}} / \mathrm{kg}$ of $\mathrm{DM}$.

${ }^{3}$ Megalac, Church and Dwight Co. Inc., Princeton, NJ.

${ }^{4}$ Protein supplement contained $89.2 \% \mathrm{DM}, 45.9 \% \mathrm{CP}$ (soluble protein: $22.0 \%$ of CP), $1.21 \% \mathrm{Ca}, 0.72 \% \mathrm{P}, 0.34 \% \mathrm{Mg}, 1.75 \% \mathrm{~K}$, and 1.87 Mcal of $\mathrm{NE}_{\mathrm{L}} / \mathrm{kg}$ of $\mathrm{DM}$.

${ }^{5}$ Energy supplement contained $88.6 \% \mathrm{DM}, 19.1 \% \mathrm{CP}$ (soluble protein: $19.0 \%$ of $\mathrm{CP}$ ), $1.52 \% \mathrm{Ca}, 0.62 \% \mathrm{P}, 0.36 \% \mathrm{Mg}, 0.92 \% \mathrm{~K}$, and 1.75 Mcal of $\mathrm{NE}_{\mathrm{L}} / \mathrm{kg}$ of DM.

${ }^{6}$ Pre-fresh grain mix contained $90.0 \% \mathrm{DM}, 18.6 \% \mathrm{CP}, 1.15 \% \mathrm{Ca}$, $0.63 \% \mathrm{P}, 0.58 \% \mathrm{Mg}, 0.77 \% \mathrm{~K}$, and $1.67 \mathrm{Mcal}$ of $\mathrm{NE}_{\mathrm{L}} / \mathrm{kg}$ of DM.

form of IMI without the confounding effects of clinical mastitis and ketosis on immune system and metabolic status. A TMR was fed to meet the nutrient requirements for lactation (NRC, 2001). Feed ingredients and nutrient composition of the lactation ration are shown in Table 1.

\section{Blood Sampling, BCS, and BW}

Blood samples were collected at wk -2 relative to EPD and at wk 1, 2, 4, and 8 postpartum at approximately $0900 \mathrm{~h}$ via coccygeal venipuncture. Blood tubes contained an anticoagulant solution $\left(\mathrm{K}_{3}\right.$-EDTA, BectonDickinson Vacutainer Systems, Franklin Lakes, NJ) and were placed on ice immediately following sampling and transferred to the laboratory within $1 \mathrm{~h}$ of collec- tion. Blood samples were centrifuged at $1,500 \times g$ at $4^{\circ} \mathrm{C}$ for 20 min, plasma was decanted, and aliquots of plasma samples were stored at $-20^{\circ} \mathrm{C}$ until analyzed.

At wk $-9,-4,-2$, and -1 (before EPD), and then at wk $1,3,5,7$, and 8 postpartum, BCS was measured on a scale of 1 to 5 ( 1 = thin, 5 = extremely overconditioned; Wildman et al., 1982) and recorded at approximately $0900 \mathrm{~h}$ by 2 trained individuals. Cows were scored to the nearest quarter point. Body weight was measured at wk $-9,-2$, and -1 (before EPD), and then each week postpartum through $8 \mathrm{wk}$ of lactation at approximately $0930 \mathrm{~h}$.

\section{Plasma Metabolites}

Plasma concentrations of triacylglycerol and cholesterol (CHL) were determined using enzymatic-colorimetric assays (Roche Diagnostics, Indianapolis, IN). Plasma concentrations of phospholipids and BHBA were also determined via enzymatic-colorimetric assays (Autokit 3-HB, Wako Chemical, Dallas, TX; Williamson and Mellanby, 1974). Plasma concentrations of apolipoprotein (apo) B were determined via a turbidimetric immunoassay (Autokit Apo B, Wako Chemical; Rifai and Warnick, 1994).

Plasma glucose (Peterson and Young, 1968) and NEFA concentrations were determined using enzymatic assays (Wako Chemical). The NEFA assay was performed according to modifications described by McCutcheon and Bauman (1986), using reduced sample $(10 \mu \mathrm{L})$ and reagent volumes $(2 \%$ and $3 \%$ of recommended volumes of reagent $A$ and reagent $B$, respectively).

Plasma Lipid-Soluble Vitamins. Plasma retinol, $\alpha$-tocopherol, and $\beta$-carotene were determined by reversed-phase HPLC with a photodiode array detector (Waters 996; Waters Corp., Milford, MA) adapted from the method developed by Barua et al. (1993) with modifications as follows. Briefly, 200- $\mu$ L plasma samples were mixed with $200 \mu \mathrm{L}$ of methanol and $50 \mu \mathrm{L}$ of axerophthene as the internal standard. Samples were extracted 3 times with $0.5 \mathrm{~mL}$ of hexane, and the hexane layer was removed via evaporation under a light flow of nitrogen gas. The residue was dissolved in $100 \mu \mathrm{L}$ of 2-propanol and applied to the instrument. Concurrent separation of vitamins was performed on a Waters C18 column (15 cm $\times 4.6 \mathrm{~mm}$, Waters Corp., Milford, MA) that was protected using a C18 guard column (Upchurch Scientific, Oak Harbor, WA). A mobile phase consisting of acetonitrile $(720 \mathrm{~mL})$, dichloromethane (120 $\mathrm{mL})$, methane $(80 \mathrm{~mL})$, and $\mathrm{n}$-butanol $(0.8 \mathrm{~mL})$ at a flow rate of $2 \mathrm{~mL} / \mathrm{min}$ was used. $\alpha$-Tocopherol, retinol, and $\beta$-carotene were detected at $\lambda=290,325$, and 450 $\mathrm{nm}$, respectively. Plasma concentrations of $\alpha$-tocoph- 
erol, retinol, and $\beta$-carotene were eluted at 3.00, 1.50, and $9.00 \mathrm{~min}$, respectively.

Plasma APP. Plasma Hpt concentrations were determined using a colorimetric assay based on the affinity for binding to free hemoglobin (TriDelta Diagnostics, Inc., Morris Plains, NJ). Plasma concentrations of albumin were determined colorimetrically using the bromocresol green method (Wako Chemical; Carfray et al., 2000).

The original immunoblotting assay developed by Burnette (1981) was adapted for determination of plasma concentrations of RBP and TTR concurrently by using polyclonal antibodies against RBP and TTR (Phoenix Pharmaceuticals Inc., Belmont, CA, and Abcam Inc., Cambridge, MA, respectively). In addition, molecular weight markers (BioRad, Richmond, CA) were applied to a lane on each gel with the plasma samples. Scans of protein bands were obtained using a digital imaging system (Kodak image station 2000 mm; Eastman Kodak Co., New Haven, CT). The density of each band (representing plasma RBP and TTR) was determined with Scion imaging software (Scion Imaging, Frederick, MD). The density of each band was calculated as a percentage of the density of a pooled bovine plasma sample that was run on each gel serving as an external standard. Plasma concentrations of RBP and TTR are reported as relative (to the external standard) percentages. Furthermore, ratios of plasma RBP to TTR relative concentrations were calculated as an indicator of APP response. The intra- and interassay coefficients of variation for RBP concentrations were 6.76 and $12.7 \%$, respectively, and those of TTR concentrations were 7.95 and $11.6 \%$, respectively.

\section{Milk Collection and Analysis}

After parturition, cows were milked 3 times daily, and milk yields were recorded at each milking. Each week, 3 consecutive milk samples were pooled, adjusted for milk yield at each milking, and analyzed for protein, fat, lactose (infrared spectroscopy), MUN, and SCC (Foss 4000 and 5000, respectively; Dairy One, Ithaca, NY). To normalize the SCC distribution, log transformation was performed and SCC is reported as linear score. Energy-corrected milk was calculated using the following equation: $\mathrm{ECM}(\mathrm{kg} / \mathrm{d})=[0.327 \times \mathrm{milk} \mathrm{kg} / \mathrm{d}]+$ $[12.96 \times($ milk fat $\mathrm{kg} / \mathrm{d})]+[7.2 \times($ milk protein $\mathrm{kg} / \mathrm{d})]$ (Tyrrell and Reid, 1965).

\section{Statistical Analyses}

All statistical analyses were conducted using SAS software (version 9.1.2 for Windows; SAS Institute Inc., Cary, NC). Somatic cell counts were $\log _{10}$ transformed and reported as SCS. Univariate and stepwise forward multivariate logistic regression analyses were used to describe the relations between binary data (occurrence of a new IMI) and the measures of energy status, plasma metabolites, APP, and vitamins (SAS Institute, 2002). The variables entered and remained in the model if $P$ $\leq 0.25$. The maximum log-likelihood test was used to determine if models were significant, and a model was declared significant at $P<0.05$. The effects of IMI status, prefresh ration and time (week), and interactions between IMI status and breed, IMI status and week, and IMI status, week, and breed on the continuous variables of energy status, plasma metabolites, APP, and vitamins were tested by the MIXED procedure of SAS. Postpartum plasma concentrations of lipid-soluble vitamins and BHBA were covariately adjusted by the prepartum (wk -2 relative to EPD) concentrations and compound symmetry was used as the covariate structure. The repeated statement used week for variables measured over week, and cow was considered a random factor. The Satterthwaite option in the model was used for estimation of degrees of freedom. Protected least significance difference was used to compare least squares means. Data are reported as least squares means \pm standard error of means (SE). Significant differences were declared at $P<0.05$.

\section{RESULTS AND DISCUSSION}

\section{General Observations}

Fifteen Holstein and 15 Jersey cows met the criteria for study selection and were included in the study. Cows that showed clinical signs of mastitis within the timeframe of the study were excluded from the final selection and no other metabolic or infectious diseases were observed in cows selected for the study within the study period. Seven Holstein and 9 Jersey cows did not develop a new IMI, and 8 Holstein and 6 Jersey cows were identified as developing a new IMI during the periparturient period (total of 14 cows with a new IMI and total of 16 cows without a new IMI). One cow required minor assistance at calving and another cow developed clinical mastitis after completion of the study.

The IMM pathogen presence during the study period for the 30 cows that completed the study is shown in Table 2. The IMM pathogens present at wk -9 (relative to EPD) were E. coli (50\% of total pathogens), Staphylococcus spp. (other than Staph. aureus; $25 \%$ of total pathogens), and Staph. aureus (25\% of total pathogens). At wk 1 postpartum, E. coli and Staphylococcus spp. comprised $56.2 \%$ of total pathogens. In addition, Strep. dysgalactiae was isolated in the mammary gland of 3 cows (18.7\% of total pathogens). At wk 4 and 8 postpar- 
Table 2. Pathogen presence at dry off (wk -9 relative to expected parturition), wk 1, 4, and 8 postpartum for Holstein and Jersey cows with $(n=14)$ or without $(n=16)$ a new IMI during early lactation

\begin{tabular}{lrrrr}
\hline & \multicolumn{4}{c}{ Week of lactation } \\
\cline { 2 - 5 } Item & \multicolumn{1}{c}{-9} & 1 & 4 & 8 \\
\hline Total cows, n & 30 & $27^{1}$ & 30 & 30 \\
Total cows with pathogens, n & 9 & 14 & 14 & 14 \\
Total pathogens, n & 12 & 16 & 17 & 15 \\
Staphylococcus spp. & 3 & 4 & 9 & 6 \\
Staphylococcus aureus & 3 & 4 & 2 & 3 \\
Streptococcus dysgalactiae & - & 3 & 1 & 1 \\
Escherichia coli & 6 & 5 & 5 & 4 \\
Klebsiella spp. & - & - & - & 1 \\
\hline
\end{tabular}

${ }^{1}$ Three cows were not sampled at wk 1 postpartum

${ }^{2}$ Staphylococci other than Staphylococcus aureus.

tum, E. coli and Staphylococcus spp. continued to represent a high proportion of pathogens present and comprised 83.3 and $66.7 \%$, respectively. The pathogens isolated in the current study are common mastitis pathogens. In a number of studies, Staphylococcus spp. and $E$. coli comprised the majority of IMM pathogens isolated (Smith et al., 1985), in agreement with the present study. There was no effect of the different parturition standard management therapies on plasma metabolites or IMM pathogen status for the Holstein and Jersey cows.

\section{Energy Components}

Body condition score decreased from wk -9 (relative to EPD) through wk 8 of lactation (Figure 1). Cows identified with a new IMI had significantly greater BCS compared with cows that did not developed a new IMI (3.42 and $3.23 \pm 0.06$, respectively; $P=0.03$ ).

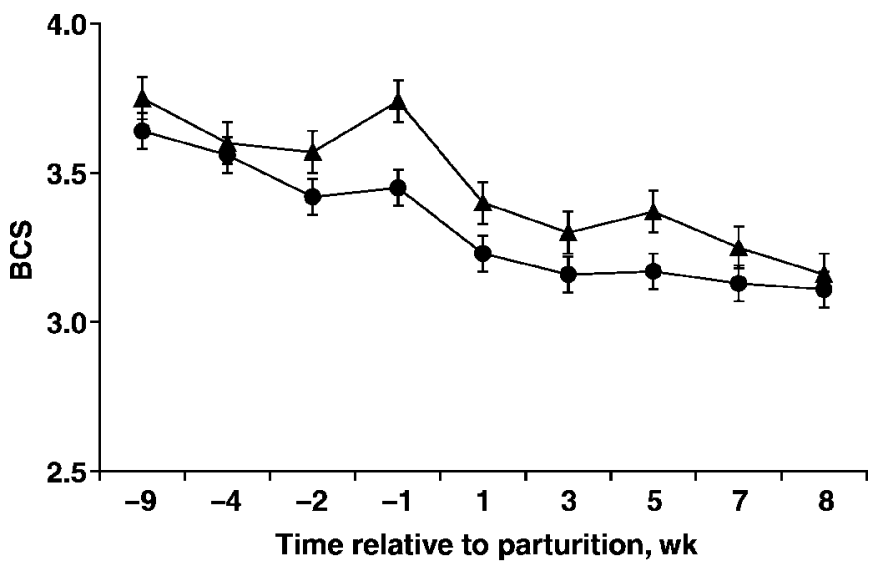

Figure 1. Least squares means and SE of BCS during the study period ( $-9 \mathrm{wk}$ prepartum through $8 \mathrm{wk}$ postpartum) for Holstein and Jersey cows with $(\boldsymbol{\Delta}, \mathrm{n}=14)$ or without $(\bullet, \mathrm{n}=16)$ a new IMI during early lactation (IMI status; $P=0.03$ ).

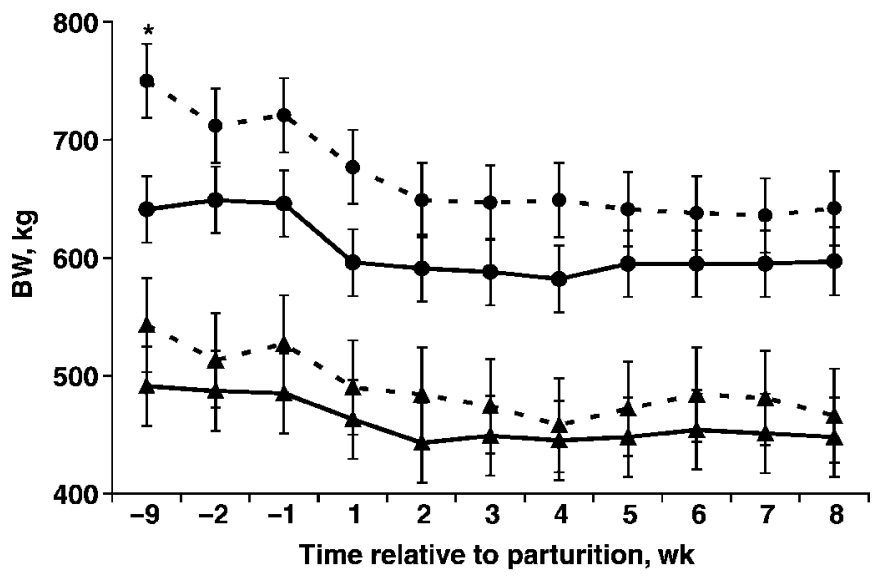

Figure 2. Least squares means and SE of BW for Holstein cows without ( $\mathrm{n}=7,-0-)$ or with ( $\mathrm{n}=8,-----)$ a new IMI, and for Jersey cows without $(\mathrm{n}=9,-\mathbf{\Delta}-)$ or with $\left(\mathrm{n}=6,--\mathbf{\Delta}_{---)}\right)$a new IMI during early lactation (breed $\times$ week $\times$ IMI; $P=0.008$ ).

Holstein cows with a new subclinical IMI had a greater BW than Holstein cows without a new IMI at wk -9 and -2 relative to EPD $(P=0.008$; Figure 2$)$. Jersey cows with or without a new IMI did not differ in BW. Greater BW and BCS during the prepartum period for cows with a new IMI indicated that these cows had greater tissue energy stores. In addition, cows identified with a new IMI lost more BW than did cows without a new IMI during the study period (126 vs. $92.1 \pm 11.5 \mathrm{~kg}$, respectively; $P=0.04$ ).

Plasma NEFA and BHBA concentrations increased at parturition as is typical of dairy cows; however, there was no association between new IMI status and plasma NEFA or BHBA (Table 3). Cows identified with a new subclinical IMI had reduced plasma concentrations of CHL compared with cows that did not develop a new IMI during the periparturient period (Table 3). Plasma concentrations of glucose, apo B, triacylglycerol, and phospholipids did not differ significantly between cows with or without a new IMI (Table 3).

High-producing cows are more susceptible to clinical diseases and metabolic disorders because of the greater metabolic demand for milk synthesis during the transition period (Suriyasathaporn et al., 2000). Fronk et al. (1980) reported that cows with excessive tissue energy stores $(\mathrm{BCS}=3.80)$ had a greater rate of mastitis than cows with moderate tissue energy stores $(\mathrm{BCS}=3.00$ ). In agreement, Gillund et al. (2001) reported that overconditioned cows (BCS $\geq 3.50$ ) were more likely to develop ketosis and mastitis than underconditioned cows. These results indicate an association between excessive tissue energy stores and impaired immune function, similar to the present study. Peripheral blood mononuclear cells from overconditioned cows $(>3.00)$ produced 
Table 3. Least squares means and SE of plasma energy metabolites, and acute phase proteins for periparturient Holstein and Jersey cows with $(n=14)$ or without $(n=16)$ a new IMI during early lactation ${ }^{1}$

\begin{tabular}{|c|c|c|c|c|c|}
\hline \multirow[b]{2}{*}{ Variable } & \multicolumn{3}{|c|}{ New IMI? } & \multicolumn{2}{|c|}{$P$-value } \\
\hline & Yes & No & SE & New IMI & New IMI $\times$ week \\
\hline $\mathrm{n}$ & 14 & 16 & & & \\
\hline NEFA, $\mu \mathrm{Eq} / \mathrm{L}$ & 290 & 228 & 37.2 & 0.22 & 0.35 \\
\hline $\mathrm{BHBA}, \mu \mathrm{mol} / \mathrm{L}$ & 560 & 570 & 30.0 & 0.81 & 0.13 \\
\hline Glucose, $\mathrm{mg} / \mathrm{dL}$ & 58.8 & 54.7 & 1.93 & 0.12 & 0.72 \\
\hline Albumin, mg/mL & 36.0 & 38.4 & 0.88 & 0.05 & 0.65 \\
\hline Haptoglobin, $\mu \mathrm{g} / \mathrm{mL}$ & 0.52 & 0.55 & 0.09 & 0.82 & 0.03 \\
\hline Retinol binding protein $(\mathrm{RBP})^{2}$ & 0.93 & 0.92 & 0.05 & 0.95 & $<0.001$ \\
\hline Transthyretin (TTR) ${ }^{2}$ & 0.88 & 0.86 & 0.05 & 0.74 & 0.05 \\
\hline RBP:TTR ratio & 1.10 & 1.08 & 0.05 & 0.71 & 0.17 \\
\hline Apolipoprotein B, mg/dL & 30.1 & 28.7 & 1.78 & 0.56 & 0.67 \\
\hline Cholesterol, mg/dL & 127 & 174 & 11.8 & 0.008 & 0.85 \\
\hline Triacylglycerol, mg/dL & 18.8 & 20.3 & 1.26 & 0.44 & 0.98 \\
\hline Phospholipid, mg/dL & 28.9 & 26.1 & 3.38 & 0.63 & 0.31 \\
\hline
\end{tabular}

${ }^{1}$ The effect of week was significant for the variables measured.

${ }^{2}$ Relative changes compared with a fixed pooled sample serving as an external standard.

less IgM and IFN- $\gamma$ when stimulated with B- and Tcell mitogens, respectively, compared with cows that had lower BCS during the periparturient period (Lacetera et al., 2005). Janosi et al. (2003) also reported that cows with elevated serum BHBA $(>1 \mathrm{mM})$ had greater risk for mastitis. Although not significant, plasma BHBA concentrations were $170 \mu \mathrm{mol} / \mathrm{L}$ greater (at wk 2 postpartum) for cows with a new IMI compared with cows that did not develop an IMI. The lack of a significant response may be related to the high variability of BHBA concentration during the periparturient period and the small sample size in the current study.

Cows without a new IMI during early lactation had greater plasma concentrations of CHL than cows with a new IMI (Table 3). LeBlanc et al. (2004) reported that the risk for mastitis tends to increase (odds ratio $=$ 1.89) as CHL concentration increases $(P=0.10)$ and concluded that the inability of the liver to export lipoproteins, by which CHL is transported, is a risk factor for developing mastitis during early lactation. Positive correlations between energy balance and plasma concentrations of glucose and CHL have been observed during early lactation (Reist et al., 2002) in agreement with present results. These studies indicated that reduced plasma CHL, in addition to NEB, was associated with an increased risk of mastitis. In the present study, however, no causal relationship could be detected. Possibly, these results may be related to suboptimal synthetic capacities of hepatocytes during the periparturient period (Bernabucci et al., 2004).

Plasma apo B concentrations did not differ by IMI status in the present study. Serum concentrations of apo B were reduced during early lactation for cows identified with ketosis (Nakagawa and Katoh, 1998).
Greater hepatic uptake of NEFA during NEB has been related to decreased apo B and very low density lipoproteins (Nakagawa and Katoh, 1998). Possibly, NEB was not severe enough to show a significant relationship with subclinical IMI status, because cows did not experience clinical ketosis in the current study. Collectively, the observations reported herein and of others demonstrate associations between indices of increased lipid mobilization during the transition period and an increased risk for developing an IMI.

\section{Plasma Lipid-Soluble Vitamins}

Plasma concentrations of $\beta$-carotene, $\alpha$-tocopherol (Figures 3 and 4, respectively), and retinol were reduced at wk 1 or 2 postpartum. Temporal patterns of change in plasma concentrations of $\beta$-carotene and retinol observed in the current study are consistent with previous reports (Chew et al., 1982). Plasma concentrations of $\beta$-carotene were significantly greater for Jersey cows with a new IMI compared with Jersey cows that did not develop a new IMI at wk $-2(10.3$ vs. $6.45 \pm 1.08$ $\mu \mathrm{g} / \mathrm{mL} ; P=0.005)$ but this relationship was reversed postpartum $(P=0.08$ and 0.005 , respectively). Jersey cows without a new IMI had significantly greater plasma concentrations of $\beta$-carotene at wk 8 compared with Jersey cows with a new IMI during early lactation. In contrast, Holstein cows with or without a new IMI did not significantly differ in plasma concentrations of $\beta$-carotene (Figure 3). Plasma concentrations of $\alpha$ tocopherol were greater for cows without a new IMI at wk 8 postpartum, regardless of breed $(P<0.001$; Figure 4). No significant differences were observed for plasma 


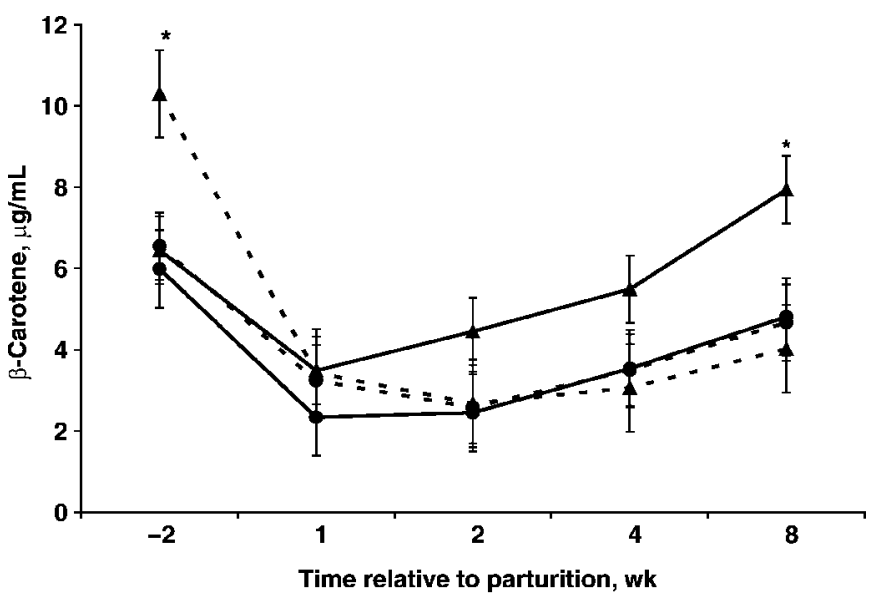

Figure 3. Least squares means and SE of plasma $\beta$-carotene for Holstein cows without $(\mathrm{n}=7,-\bullet-)$ or with $(\mathrm{n}=8,------)$ a new IMI, and for Jersey cows without $(\mathrm{n}=9,-\boldsymbol{\Delta}-)$ or with $(\mathrm{n}=6$, --- $\mathbf{\Delta - - - )}$ a new IMI during early lactation. The effect of breed $\times$ week $\times$ IMI is significant $(P=0.003)$. Jersey cows with a new IMI had greater plasma concentrations of $\beta$-carotene at wk -2 (prepartum; $P=$ $0.005)$ but reduced plasma concentrations of $\beta$-carotene postpartum at wk $4(P=0.08)$ and wk $8(P=0.005)$ compared with Jersey cows without a new IMI. Holstein cows with or without a new IMI did not differ in plasma concentrations of $\beta$-carotene.

retinol concentrations in cows with or without a new IMI.

Similar to the current study, Johnston and Chew (1984) observed that plasma concentrations of $\beta$-carotene were greater in cows with mastitis than in those without an IMI during the periparturient period. The relationship between a reduction in plasma $\beta$-carotene

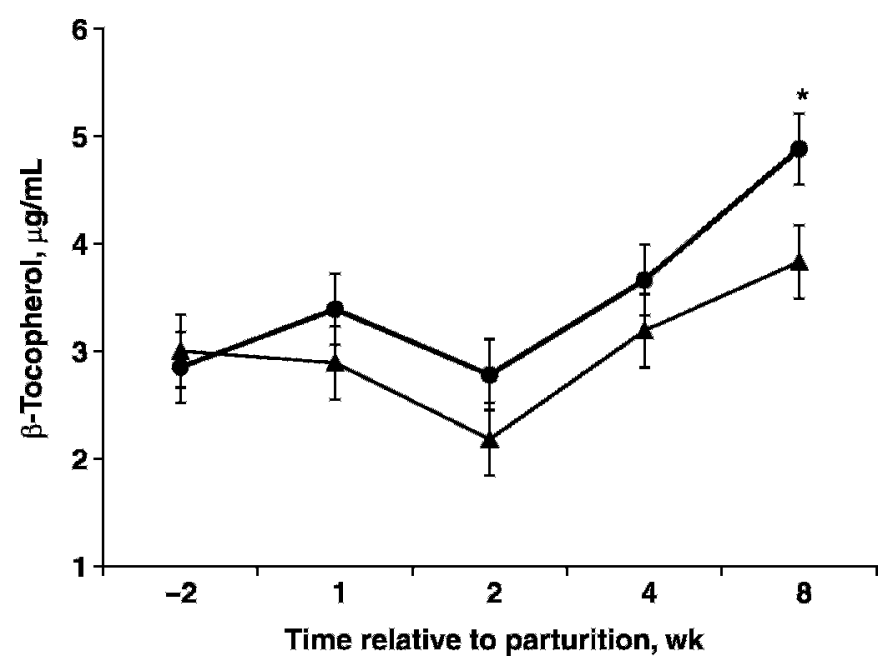

Figure 4. Least squares means and SE of plasma concentrations of $\alpha$-tocopherol ( $\mu \mathrm{g} / \mathrm{mL}$ ) during the periparturient period for Holstein

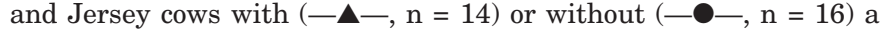
new IMI during early lactation (IMI $\times$ week; $P<0.001$ ). and increased risk of a new IMI is not fully understood but may be related to the antioxidant activity of $\beta$ carotene. $\beta$-Carotene has been shown to quench highly reactive singlet oxygen and also reacts with peroxyl radicals (Palozza and Krinsky, 1991), thus protecting cells from oxidative damage. As lactation ensued, however, plasma concentrations of $\beta$-carotene did not recover toward prepartum concentrations for the Jersey cows with a new IMI. Possibly, the antioxidant activity of $\beta$-carotene was reduced for Jersey cows that developed a new IMI. This observation, taken together with reduced plasma $\alpha$-tocopherol for cows with a new IMI, suggests that antioxidant capacity of the cows with subclinical mastitis was lower than that of cows without subclinical mastitis. It was demonstrated that when cows were fed diets supplemented with $\beta$-carotene, there was a greater killing ability of leukocytes against Staph. aureus during the periparturient period (Michal et al., 1994). Increased dietary supplementation of $\beta$ carotene was associated with a reduced incidence and severity of IMI in dairy cows (Chew et al., 1982; Dahlquist and Chew, 1985). It is unknown why there were opposing associations between plasma $\beta$-carotene and new IMI status for Jersey cows during the prepartum period vs. the postpartum period in the current study.

In the present study, plasma concentrations of $\alpha$ tocopherol decreased as parturition approached, reached the nadir during wk 1 to wk 2 postpartum, and then recovered toward prepartum concentrations, as previously reported (Weiss et al. 1990). Cows without a new IMI had significantly greater plasma concentrations of $\alpha$-tocopherol at wk 8 than cows with a new IMI. In agreement with the present study, Atroshi et al. (1986) reported that cows that developed mastitis during early lactation had reduced plasma and milk concentrations of $\alpha$-tocopherol. LeBlanc et al. (2004), however, did not detect a significant association between risk for developing clinical mastitis during early lactation and serum concentrations of $\alpha$-tocopherol. The authors concluded that the lack of a significant association may have been related to the fact that most cows in that study received dietary $\alpha$-tocopherol supplementation during the prepartum period (LeBlanc et al., 2004). The lack of a consistent association between new IMI status and plasma $\alpha$-tocopherol concentrations in the present study may be related to the small sample size $(\mathrm{n}=30)$ compared with larger epidemiological studies and lower severity of mastitis in the present study (LeBlanc et al., 2004). Another possible explanation may be due to adequate plasma $\alpha$-tocopherol status in cows from the present study. Hogan et al. (1993) suggested that plasma concentrations of $\alpha$-tocopherol in the range of 3.5 to $4.0 \mu \mathrm{g} / \mathrm{mL}$ are needed for optimal cell function. Weiss et al. (1997) determined that $3.00 \mu \mathrm{g}$ of $\alpha$-tocoph- 


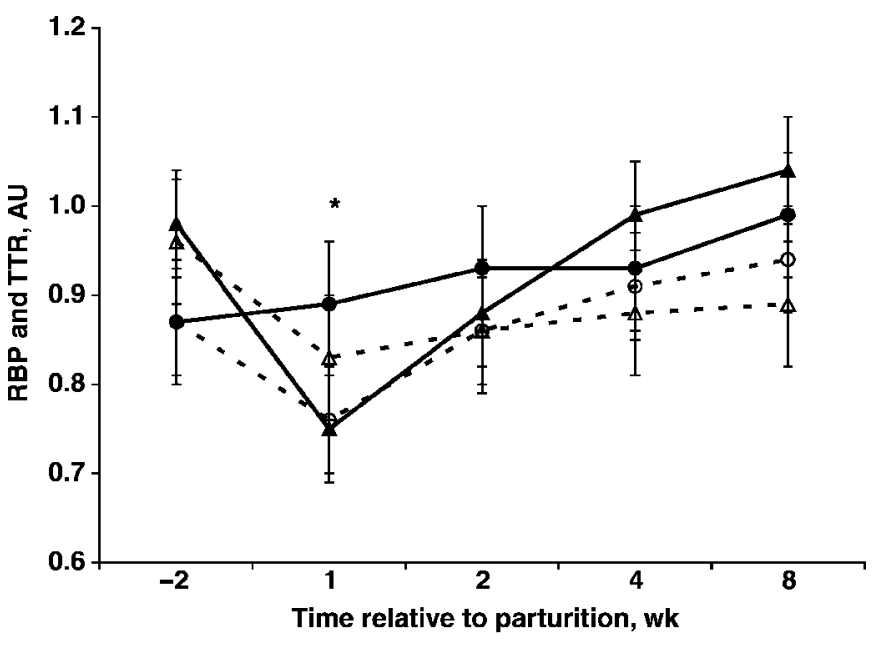

Figure 5. Least squares means and SE of plasma concentrations (arbitrary units, AU) of retinol binding protein (RBP) and transthyretin (TTR) during the periparturient period for Holstein and Jersey cows with (- $-\boldsymbol{\Delta}-$ and --- $\triangle---$ for RBP and TTR, respectively; $\mathrm{n}=14$ ) or without (- - and --- $\bigcirc---$ for RBP and TTR, respectively; $\mathrm{n}=16$ ) a new IMI during early lactation. Plasma RBP and TTR are reported as relative changes when compared with a fixed pooled sample serving as an external standard. The effect of IMI $\times$ week is significant for plasma RBP concentrations at wk $1(P=0.03)$.

erol/mL of plasma was associated with effective neutrophil function and a reduction in mastitis (Weiss et al., 1997). Plasma $\alpha$-tocopherol concentrations in the current study in both groups were within this range (3.00 to $3.50 \mu \mathrm{g} / \mathrm{mL}$ ). Therefore, it can be concluded that $\alpha$ tocopherol status in cows with subclinical mastitis was not associated with risk of mastitis when plasma concentrations were greater than $3.00 \mu \mathrm{g} / \mathrm{mL}$. In the present study, a greater decrease or lower plasma $\beta$-carotene concentrations were observed for Jersey cows with a subclinical IMI compared with Jersey cows that did not develop a new IMI, with no association noted for Holstein cows. These breed differences in the relationship between lipid-soluble vitamin status and mastitis warrant further study.

\section{Plasma APP}

Cows without a new IMI had greater plasma concentrations of albumin compared with cows that developed a new IMI, as expected (Table $3 ; P=0.05$ ). Plasma Hpt concentrations were greater at wk 1 postpartum for cows without a new IMI (data not shown, $P=0.06$ ). Temporal changes in plasma concentrations of RBP and TTR paralleled that of plasma retinol. Both RBP and TTR plasma concentrations were reduced at wk 1 postpartum relative to wk -2 (Figure $5 ; P<0.001$ ), except for RBP in cows identified without a new IMI. Cows with a new IMI had reduced plasma concentrations of
RBP at wk 1 postpartum compared with cows that did not develop a new IMI $(P=0.03)$. No significant differences were observed for TTR or the RBP:TTR ratio between cows with or without a new IMI.

Plasma albumin and Hpt concentrations are indicators of inflammation and infection. Plasma albumin concentrations have been shown to decrease and $\mathrm{Hpt}$ concentrations increase at parturition and during inflammation and infection (Bernabucci et al., 2004; Humblet et al., 2006). Plasma concentrations of Hpt increased, however, at wk 1 postpartum in cows without a new IMI. This was unexpected, because Hpt has been shown to increase with inflammation (Humblet et al., 2006). Possibly, the sampling frequency may not have been sufficient in the present study to detect the peak of plasma Hpt in cows with a new IMI, or the subclinical IMI did not elicit a strong immune response affecting Hpt concentration. Increased serum concentration of Hpt for cows during wk 1 after parturition has been previously reported (Humblet et al., 2006) and was observed in the present study.

Plasma RBP and TTR concentrations were reduced during an inflammation by LPS, because of induction of the transcription factor nuclear factor interleukin- 6 (NF-IL-6) by proinflammatory cytokines such as IL-1, IL-6, and tumor necrosis factor- $\alpha$ (Rosales et al., 2000). In the current study, occurrence of a new IMI was associated with a significant reduction in plasma RBP at wk 1 postpartum. This is the first report to describe reduction of plasma RBP concentrations because of occurrence of a new IMI in dairy cattle. This decrease in $\mathrm{RBP}$ did not result in a decrease in plasma retinol, which would be expected because RBP is the transporter for retinol. Dietary protein intake can alter RBP synthesis and release. Lindberg et al. (1999) reported that periparturient cows fed a higher dietary CP ration (approximately 16\% of DM) had greater serum RBP concentrations compared with cows fed a lower CP ration (approximately 13\% of DM). Increases in protein and amino acid requirements during disease and infection have been previously reported (Obled et al., 2002). In the present study, feed intake was not measured and may have differed by IMI status. Because plasma albumin concentration is a sensitive indicator of protein status, the decrease in both plasma RBP and albumin concentrations in the present study suggested that dietary protein may be limited in cows with a new IMI during the periparturient period. This view, however, does not exclude other contributing metabolic- or disease-related factors.

In agreement with the current study, Poso and Lindberg (1994) reported that plasma TTR concentration was reduced in cows during early lactation compared with cows during the dry period, and they suggested that 
Table 4. Least squares means and SE of milk yield and milk composition for Holstein and Jersey cows with $(\mathrm{n}=14)$ or without $(\mathrm{n}=16)$ a new IMI during the first $8 \mathrm{wk}$ of lactation ${ }^{1}$

\begin{tabular}{|c|c|c|c|c|c|}
\hline \multirow[b]{2}{*}{ Variable } & \multicolumn{3}{|c|}{ New IMI? } & \multicolumn{2}{|c|}{$P$-value } \\
\hline & Yes & No & $\mathrm{SE}$ & New IMI & New IMI $\times$ week \\
\hline $\mathrm{n}$ & 14 & 16 & & & \\
\hline \multicolumn{6}{|l|}{ Yield, kg/d } \\
\hline Milk & 37.2 & 34.8 & 1.62 & 0.27 & 0.99 \\
\hline $\mathrm{ECM}^{2}$ & 38.3 & 36.6 & 1.22 & 0.29 & 0.66 \\
\hline Milk fat & 1.29 & 1.20 & 0.08 & 0.43 & 0.62 \\
\hline Milk protein & 1.11 & 1.13 & 0.03 & 0.75 & 0.65 \\
\hline Milk lactose & 1.70 & 1.68 & 0.07 & 0.80 & 0.99 \\
\hline \multicolumn{6}{|c|}{ Milk composition } \\
\hline Fat, $\%$ & 3.64 & 3.62 & 0.24 & 0.96 & 0.83 \\
\hline Protein, \% & 3.10 & 3.30 & 0.06 & 0.02 & 0.09 \\
\hline Lactose, \% & 4.59 & 4.79 & 0.04 & $<0.001$ & 0.71 \\
\hline MUN, mg/dL & 12.8 & 14.9 & 0.70 & 0.03 & 0.76 \\
\hline SCS & 5.02 & 1.03 & 0.39 & $<0.001$ & $<0.001$ \\
\hline
\end{tabular}

${ }^{1}$ The effect of week was significant for the variables measured.

${ }^{2} \mathrm{ECM}=[0.372 \times($ milk kg/d $)]+[2.95 \times($ milk fat $\mathrm{kg} / \mathrm{d})]+[7.2 \times($ milk protein $\mathrm{kg} / \mathrm{d})] ;$ Tyrrell and Reid (1965)

synthetic and export capacities of the hepatic tissues are compromised in cows with hyperketonemia. In the present study, cows did not have clinical signs of mastitis or ketosis, and only plasma albumin and RBP were significantly reduced in cows with a new IMI. The reduction of these components alternatively indicates reduced protein status for cows with a new IMI.

\section{Milk Production and Composition}

Yields of milk, ECM, milk fat, milk protein, and milk lactose did not differ significantly between cows with or without a new IMI during early lactation (Table 4). Cows with a new IMI had reduced concentrations of milk protein $(P=0.02)$, milk lactose $(P<0.001)$, and MUN $(P=0.03)$ and greater milk SCS $(P<0.001)$ compared with cows that did not develop a new IMI. Increased risk of developing a new IMI during early lactation was associated with increased milk SCS $(P=0.02)$, as expected (Sargeant et al., 2001). An increase of 1 unit in milk SCS was associated with an 8.37-fold increase in risk for developing a new IMI (confidence interval = 1.45 to 48.8 ). No other milk components were affected by IMI status.

Decreased milk protein percentage for cows with a new IMI is in agreement with other reports and is primarily because of a reduction in milk casein synthesis (Harmon, 1994). Reduced MUN in cows with a new IMI may be explained in the context of the whole-animal protein status during the transition period. Amino acids derived from feed and tissue can be used as an energy source during NEB. Chilliard and Robelin (1983) determined that approximately $14.7 \mathrm{~kg}$ of tissue protein was mobilized in high-producing cows during early lactation when feed intake was restricted. It was also demon- strated that mobilization of body protein made a small but significant contribution to the total empty body energy mobilized (Andrew et al., 1994). In addition, several studies cited by Obled et al. (2002) demonstrated that during inflammation and disease states, the requirements for some AA were significantly increased. These findings and those of the current study lend support to the hypothesis that a transient protein deficiency during early lactation may, in part, explain reduced concentrations of some plasma and milk proteins. Reduced MUN, milk protein, and lactose synthesis taken together with the reductions in plasma albumin and RBP in cows with a new IMI may indicate a transient dietary protein deficiency.

\section{CONCLUSIONS}

Cows identified with a new subclinical IMI had greater prepartum BCS, BW, and greater BW loss compared with cows that did not develop a new IMI. These observations are indicative of greater tissue energy mobilization. Postpartum plasma concentrations of $\alpha$-tocopherol and CHL were reduced in cows with a new IMI, as previously observed. There was a significant delay in recovery of plasma concentrations of $\beta$-carotene postpartum for Jersey cows with a new IMI. Although plasma retinol was not significantly influenced by IMI status, plasma albumin and RBP were reduced in cows with a new IMI. These decreases in plasma proteins taken together with decreases in milk protein percentage, MUN, and lactose may indicate a dietary protein deficiency in cows identified with a new IMI during early lactation; however, other nutritional components may have influenced these alterations. Breed differed in aspects of lipid-soluble vitamins in relation to occur- 
rences of subclinical IMI. This observation may be related to breed differences in their immune response to, and risk of, a new IMI during early lactation. Overall, periparturient cows with greater tissue energy stores prepartum and reduced plasma proteins, $\beta$-carotene, and $\alpha$-tocopherol had a greater risk for developing a new IMI during the periparturient period.

\section{ACKNOWLEDGMENTS}

The authors thank David Schreiber Jr., Richard M. Clark, L. Cameron Faustman, and Charles Giardina for technical assistance, and the American Jersey Cattle Association for partial support of this study. Appreciation for animal care is extended to Arnold Nieminen and Mary Margaret Cole, former manager and manager, respectively, of the Kellogg Dairy Center at the University of Connecticut.

\section{REFERENCES}

Andrew, S. M. 2000. Effect of fat and protein content of milk from individual cows on the specificity rates of antibiotic residue screening tests. J. Dairy Sci. 83:2992-2997.

Andrew, S. M., D. R. Waldo, and R. A. Erdman. 1994. Direct analysis of body composition of dairy cows at three physiological stages. J. Dairy Sci. 77:3022-3033.

Atroshi, F., J. Tyoponnen, S. Sankari, R. Kangasniemi, and J. Parantainen. 1986. Possible roles of vitamin $\mathrm{E}$ and glutathione metabolism in bovine mastitis. Int. J. Vitam. Nutr. Res. 57:37-43.

Barua, A. B., H. C. Furr, D. Janick-Buckner, and J. A. Olson. 1993. Simultaneous analysis of individual carotenoids, retinol, retinyl esters, and tocopherols in serum by isocratic non aqueous reversed phase HPLC. Food Chem. 46:419-424.

Bernabucci, U., B. Ronchi, L. Basirico, D. Pirazzi, F. Rueca, N. Lacetera, and A. Nardone. 2004. Abundance of mRNA of apolipoprotein B-100, apolipoprotein E, and microsomal triglyceride transfer protein in liver from periparturient cows. J. Dairy Sci. 87:2881-2888.

Bernabucci, U., B. Ronchi, N. Lacetera, and A. Nardone. 2005. Influence of body condition score on relationships between metabolic status and oxidative stress in periparturient dairy cows. J. Dairy Sci. 88:2017-2026.

Burnette, W. N. 1981. "Western blotting": Electrophoretic transfer of proteins from sodium dodecyl sulfate-polyacrylamide gels to unmodified nitrocellulose and radiographic detection with antibody and radioiodinated protein A. Anal. Biochem. 112:195-203.

Carfray, A., K. Patel, P. Whitaker, P. Garrick, G. J. Griffiths, and G. L. Warwick. 2000. Albumin as an outcome measure in haemodialysis in patients: The effect of variation in assay method. Nephrol. Dial. Transplant 15:1819-1822.

Chew, B. P., L. L. Hollen, J. K. Hillers, and M. L. Herlugson. 1982. Relationship between vitamin A and $\beta$-carotene in blood plasma and milk and mastitis in Holsteins. J. Dairy Sci. 65:2111-2118.

Chilliard, Y., and J. Robelin. 1983. Mobilization of body proteins by early lactating cows measured by slaughter and $\mathrm{D}_{2} \mathrm{O}$ dilution techniques. Page 195 in Proc. 4th Int. Symp. Protein Metab. Nutr. Rech. Agron. Publ., Clermont-Ferrand, France.

Dahlquist, S. P., and B. P. Chew. 1985. Effects of vitamin A and $\beta$ carotene on mastitis in dairy cows during the early dry period. J. Dairy Sci. 69(Suppl. 1):119. (Abstr.)

Duffield, T. F. 2000. Subclinical ketosis in lactating dairy cattle. Page 231-253 in Metabolic disorders of Ruminants. Vet. Clin. North Am. Food Anim. Pract. W. B. Saunders Company, Philadelphia, PA.
Erskine, R. J., P. C. Barlett, T. Herdt, and P. Gaston. 1997. Effects of parenteral administration of vitamin $\mathrm{E}$ on health of periparturient dairy cows. J. Am. Vet. Med. Assoc. 211:466-469.

Fronk, T. J., L. H. Schultz, and A. R. Hardie. 1980. Effect of dry period over-conditioning on subsequent metabolic disorders and performance of dairy cows. J. Dairy Sci. 63:1080-1090.

Gillund, P., O. Reksen, Y. T. Grohn, and K. Karlberg. 2001. Body condition related to ketosis and reproductive performance in Norwegian dairy cows. J. Dairy Sci. 84:1390-1396.

Goff, J. P., and R. L. Horst. 1997. Physiological changes at parturition and their relationship to metabolic disorders. J. Dairy Sci. 80:1260-1268.

Grohn, Y., and L. A. Lindberg. 1985. Ultrastructural changes of the liver in spontaneously ketotic dairy cows. J. Comp. Pathol. 95:443-452.

Harmon, R. J. 1994. Physiology of mastitis and factors affecting somatic cell counts. J. Dairy Sci. 77:2103-2112.

Hogan, J. S., D. M. Galton, R. J. Harmon, S. C. Nickerson, S. P. Oliver, and J. W. Pankey. 1990. Protocols for evaluation efficacy of post-milking teat dips. J. Dairy Sci. 73:2580-2585.

Hogan, J. S., W. P. Weiss, and J. S. Smith. 1993. Role of vitamin $\mathrm{E}$ and selenium in host defense against mastitis. J. Dairy Sci. 76:2795-2803.

Humblet, M. F., H. Guyot, B. Boudry, F. Mbayahi, C. Hanzen, F. Rollin, and J. M. Godeau. 2006. Relationship between haptoglobin, serum amyloid A, and clinical status in a survey of dairy herds during a 6-month period. Vet. Clin. Pathol. 35:188-193.

Janosi, S., M. Kulscar, P. Corodi, L. Katai, J. Reiczigel, S. J. Dieleman, J. A. Nikoloc, G. Salyi, P. Ribiczey-Szabo, and G. Huszenicza. 2003. Energy imbalance related predisposition to mastitis in group fed high producing postpartum dairy cows. Acta Vet. Hung. $51: 409-424$.

Johnston, L. A., and B. P. Chew. 1984. Peripartum changes of plasma and milk vitamin $\mathrm{A}$ and $\beta$-carotene among dairy cows with or without mastitis. J. Dairy Sci. 67:1832-1840.

Lacetera, N., D. Scalia, U. Bernabucci, B. Ronchi, D. Pirazzi, and A. Nardone. 2005. Lymphocyte functions in overconditioned cows around parturition. J. Dairy Sci. 88:2010-2016.

LeBlanc, S. J., T. H. Herdt, W. M. Seymour, T. F. Duffield, and K. E. Leslie. 2004. Peripartum serum vitamin E, retinol, and $\beta$ carotene in dairy cattle and their associations with disease. J. Dairy Sci. 87:609-619.

Lindberg, L. A., H. Sinkkonen, A. R. Poso, A. T. Tesfa, and J. Schroder. 1999. Production of monoclonal antibodies and enzyme immunoassay to bovine retinol-binding protein and determination of retinol-binding protein serum levels and retinol concentrations in serum and liver in dairy cows before and after parturition. Res. Vet. Sci. 66:259-263.

McCutcheon, S. N., and D. E. Bauman. 1986. Effect of chronic growth hormone treatment on responses to epinephrine and thyrotropinreleasing hormone in lactating cows. J. Dairy Sci. 69:44-51.

Michal, J. J., L. R. Heinman, T. S. Wong, and B. P. Chew. 1994. Modulatory effects of dietary $\beta$-carotene on blood and mammary leukocyte function in peripartum dairy cows. J. Dairy Sci. 77:1408-1421.

Nakagawa, H., and N. Katoh. 1998. Reduced activity of lecithin: cholesterol acyltransferase in the serum of cows with ketosis and left displacement of the abomasum. Vet. Res. Commun. 22:517-524.

National Research Council. 2001. Nutrient Requirements of Dairy Cattle. 7th rev. ed. National Academy Press, Washington, DC.

Obled, C., I. Papet, and D. Breuille. 2002. Metabolic bases of amino acid requirements in acute disease. Curr. Opin. Clin. Nutr. Metabolic Care 5:189-197.

Oldham, E. R., R. J. Eberhart, and L. D. Muller. 1991. Effects of supplemental vitamin $\mathrm{A}$ or $\beta$-carotene during the dry period and early lactation on udder health. J. Dairy Sci. 74:3775-3781.

Palozza, P., and N. I. Krinsky. 1991. The inhibition of radical-initiated peroxidation of microsomal lipids both $\alpha$ - and $\beta$-carotene. Free Radic. Biol. Med. 11:407-414. 
Peterson, J. I., and D. S. Young. 1968. Evaluation of the hexokinase/ glucose-6-phosphate dehydrogenase method of determination of glucose in urine. Anal. Biochem. 23:301-316.

Poso, A. R., and L. A. Lindberg. 1994. Plasma protein synthesis and serum amino acids in dry and lactating dairy cows. J. Vet. Met. 41:72-75.

Reist, M., D. Erdin, D. von Euw, K. Tschuemperlin, H. Leuenberger, Y. Chilliard, H. M. Hammon, C. Morel, C. Philipona, Y. Zbinden, N. Kuenzi, and J. W. Blum. 2002. Estimation of energy balance at the individual and herd level using blood and milk traits in high-yielding dairy cows. J. Dairy Sci. 85:3314-3327.

Rifai, N., and G. R. Warnick. 1994. Laboratory Measurement of Lipids, Lipoproteins, and Apolipoproteins. American Association of Clinical Chemistry Press, Washington, DC.

Rosales, F. J., J. D. Topping, J. E. Smith, A. H. Shankar, and A. C. Ross. 2000. Relation of serum retinol to acute phase proteins and malarial morbidity in Papua New Guinea children. Am. J. Clin. Nutr. 71:1582-1588.

Sargeant, J. M., K. E. Leslie, J. E. Shirley, B. J. Pulkrabek, and G. H. Lim. 2001. Sensitivity and specificity of somatic cell count and California mastitis test for identifying intramammary infection in early lactation. J. Dairy Sci. 84:2018-2024.

SAS Institute. 2002. SAS User's Guide: Statistics. Version 9 ed. SAS Inst., Inc., Cary, NC.
Smith, K. L., D. A. Todhunter, and P. S. Scheonberger. 1985. Environmental mastitis: cause, prevalence, prevention. J. Dairy Sci. $67: 1531-1553$.

Suriyasathaporn, W., C. Heuer, E. N. Noordhuizen-Stassen, and Y. H. Schukken. 2000. Hyperketonemia and the impairment of udder defense: A review. Vet. Res. 31:397-412.

Tjoelker, L. W., B. P. Chew, T. S. Tanaka, and L. R. Daniel. 1990. Effect of dietary vitamin $A$ and $\beta$-carotene on polymorphonuclear leukocyte and lymphocyte function in dairy cows during the early dry period. J. Dairy Sci. 73:1017-1022.

Tyrrell, H. F., and J. T. Reid. 1965. Prediction of the energy value of cow's milk. J. Dairy Sci. 48:1215-1223.

Weiss, W. P., J. S. Hogan, K. L. Smith, and K. H. Hoblet. 1990. Relationships among selenium, vitamin E, and mammary gland health in commercial dairy herd. J. Dairy Sci. 73:381-390.

Weiss, W. P., J. S. Hogan, D. A. Todhunter, and K. L. Smith. 1997. Effects of vitamin E supplementation in diets with low concentration of selenium on mammary gland health of dairy cows. J. Dairy Sci. 80:1728-1737.

Wildman, E. E., G. M. Jones, P. E. Wagner, R. L. Boman, H. F. Troutt, Jr., and T. N. Lesch. 1982. A dairy cow body condition scoring system and its relationship to selected production characteristics. J. Dairy Sci. 65:495-501.

Williamson, D. H., and J. Mellanby. 1974. D-(-)-3-hydroxybutyrate. Pages 1836-1840 in Methods of Enzymatic Analysis. Vol. 4. H. U. Bergmeyer, ed. Academic Press, London, UK. 